\author{
International Journal of Economics, Business and Accounting Research (IJEBAR) \\ Peer Reviewed - International Journal \\ Vol-4, Issue-2, 2020 (IJEBAR) \\ E-ISSN: 2614-1280 P-ISSN 2622-4771 \\ https://jurnal.stie-aas.ac.id/index.php/IJEBAR
}

\title{
THE EFFECT OF SERVICE QUALITY EDUCATION ACADEMIC AND FACILITIES STUDENT SATISFACTION
}

\author{
Lorine Kalista Noor1, Fey Fey Tanzil2, \\ 1,2Faculty of Economics and Business Mulawarman University \\ Email:1k.noor@hotmail.com, chenvey1826@gmail.com
}

\begin{abstract}
This study aims to assess whether the service quality of academic and educational facilities affects either jointly or partially on student satisfaction. The population in this study were students numbered 130, the number of samples taken as many as 88 students. Data collection instrument used was a questionnaire using Likert scale which is based on the construction summarized from various theories that translate them into operational variable, while the testing of research instruments is done through validity and reliability test. Hypothesis testing is done using a multiple linear regression analysis. The results showed that (1) Taken together there is the influence of academic services and facilities quality education to student satisfaction,
\end{abstract}

Keywords: $\quad$ Quality of Academic Services, Educational Facilities, and Student Satisfaction

\section{Introduction}

Academic services is an integral part of all educational activities conducted. Academic activity becomes an issue that needs the attention of all of its components in the development of academic performance is very in touch with the dimensions of service quality dimensions such as that raised by(Dora, 2017) ie reliability, responsiveness, assurance, empathy and tangible, so that students who are served are satisfied. Student satisfaction is the most important element and should be a major concern for both public and private universities because students are the subject of the most instrumental in the university's existence. Without students, the college would not exist. Each college should be able to give satisfaction, so that students do not run into college competitors.

In connection with the satisfaction of students deemed necessary to evaluate all the educational management activities, both in financial, social, external and internal environment. One of the internal environments is the student as an agent for service users need special attention, because of the student will have an impact to the external environment is the general public who will assess the performance of education.

Aside from the service quality factors, factors of educational facilities can not be dismissed. The facilities are all aspects related to the physical infrastructure supporting the learning process both academic and non-academic. Examples of such facilities are space, equipment, books and computers.(Usman, 2010)is a facility is the provision of physical paraphernalia to provide convenience to the user in carrying out his activities or kegiatankegiatannya, so that all those needs can be met properly. Facilities owned by educational institutions such as universities should be a facility that can support teaching and learning activities in order to run properly and achieve maximum results where these facilities can be used by lecturers to teach and be used by students to learn and perform other activities useful as a means of developing the talents and abilities of students. The types of facilities, among others, may include libraries, laboratories, computer centers and the internet, language education programs, office that serves alumni and so forth. Based on the above rationale, the authors wanted to do research on the Influence of Service Quality for Academic and Educational Facilities on Student Satisfaction 


\author{
International Journal of Economics, Business and Accounting Research (IJEBAR) \\ Peer Reviewed - International Journal \\ Vol-4, Issue-2, 2020 (IJEBAR) \\ E-ISSN: 2614-1280 P-ISSN 2622-4771 \\ https://jurnal.stie-aas.ac.id/index.php/IJEBAR
}

\title{
2. Literature Review
}

\subsection{Quality of Academic Services}

Quality (Quality) are dynamic continues to move, if moving forward is said to be improving the quality, if the quality is said to be moving backwards downhill.(Napitupulu et al., 2018)Quality can mean superiority or excellence that exceeds the general standard. Something can be said to be qualified if there is a match between the terms that are owned by objects or services desired by the intent of the person who wishes academic service quality is the ratio between the perceived academic services customers or stakeholders with the expected quality of academic services customers or stakeholders). If the perceived quality of academic services to equal or exceed the quality of service expected in the service quality is said.

Quality is also a major component or create a user or a service provider or service melengkapan or change services(Personal \& Archive, 2017) Quality assurance of the academic excellence to meet the requirements of regular monitoring and evaluation of all relevant units of the provision of services (Mestrovic, 2018). Services are activities or serangakaian activities invisible that occurs because of the interaction between users and employees or other things that are provided by the service provider company that aims to solve the problem of a user or subscriber, generally reflecting the industry sectors intangible or specific such as education, care, health , telecommunications, transportation, insurance, banking, hotels and so on(Made Yudana \& Nyoman Natajaya, 2013). The quality of academic services are provided by the customer values the extent of academic services are provided in accordance with customer expectations(Shaylide, 2014), Customers in this case the student would say that academic service quality if it according to their specifications. The quality of academic services in this study is the value given on how good the academic services provided able to match the expectations of students.

\subsection{Education Facilities}

According to (Nugroho, Cahyono, \& Suryawirawan, 2018)is a facility is providing physical perlengkapanperlengkapan to provide convenience to the user in performing aktivitasaktivitasnya or kegiatankegiatannya, so that all those needs can be met properly. Facilities owned by educational institutions such as universities should be a facility that can support teaching and learning activities in order to run properly and achieve maximum results where these facilities can be used by faculty to teach and be used by students to learn and perform other activities which is useful as a means of developing the talents and abilities of students.

The educational facilities at the college represents support for the implementation of the process of academic services. Amenities in education means everything physical and material, which can facilitate the implementation process of learning, such as the availability of a place of learning, classroom supplies, teaching aids learning, textbooks, library, pratikum equipment and laboratory fittings. Real form at the college facilities such as campus buildings, classrooms, laboratories, internet facilities, library, cafeteria, classroom equipment that can be used in the learning process. The dimensions of the college facilities include flexibility, structuring, good quality, feasibility of use, completeness, according to need, academic support, good design,(Azam, 2018)

\subsection{Student Satisfaction}

Besifat satisfaction is an individual. Each individual has a level of satisfaction varies according to the value system that applies the higher the perceived assessment of the activity in accordance with the desires of the individual, the higher the satisfaction with the activity. Thus it can be said that satisfaction is an evaluation that describes someone on feeling happy or not happy attitude in the activity. Customer satisfaction is the level of feeling that someone claimed the comparison of the performance of the products or services received and the expected(Marthalina, 2018). 


\author{
International Journal of Economics, Business and Accounting Research (IJEBAR) \\ Peer Reviewed - International Journal \\ Vol-4, Issue-2, 2020 (IJEBAR) \\ E-ISSN: 2614-1280 P-ISSN 2622-4771 \\ https://jurnal.stie-aas.ac.id/index.php/IJEBAR
}

According to(Chandra, Ng, Chandra, and Priyono, 2018)satisfaction is the level of feeling where someone stated results of the comparison of the performance of products (services) received as expected. Satisfaction is the level of one's feelings after comparing the performance (results) are perceived with expectations(Kurbani, 2017) Many benefits can be obtained by the company with the achievement of a high level of satisfaction. High satisfaction will create loyal customers that want to buy back the goods or services, consumers want to promote the products or services kecalon other consumers. Departing from the basic concept of customer satisfaction, higher education is essentially a service industry that provides services or educational services which aim to provide satisfaction to its customers (students). Student satisfaction will be achieved when there is a match between the academic services provided to students with student expectations(Saif, 2014) academic student satisfaction for services received visits from the correspondence between expectations and performance of the services received.

\title{
2.4 Framework
}

Briefly framework underlying this study is illustrated into the following chart:

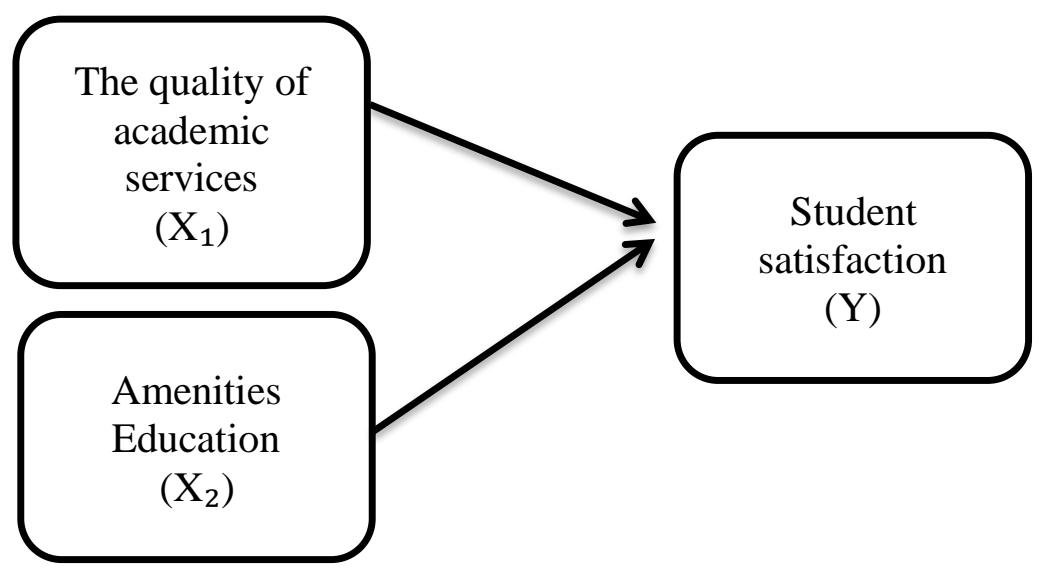

Figure 1. Framework

\subsection{Research Hypothesis}

From the formulation of the problem, research objectives, the theoretical basis and has poured in a frame of mind, it can be hypothesized as follows:

a. estimated the quality of academic services and educational facilities affects the student satisfaction

b. Anticipated academic service quality effect on satisfaction

c. Anticipated educational facilities affects the student satisfaction

Hypothesis is a temporary statement or the most probable allegation that still needs to be sought (Sugiyono, 2012: 93). Based on the concepts and results of the empirical study, the researchers propose several hypotheses in this study as follows:

H1: There is a significant effect between Customer Satisfaction on Customer Loyalty.

$\mathrm{H} 2$ : There is a significant effect between Switching Barriers on Customer Loyalty.

\section{Research Methods}

The data used in this study are primary data and sekuder. Secondary data comes from books and journals. The primary data sourced from respondents through questionnaires. Population is a generalization region consisting of objects or subjects that have quality and characteristics defined by the researchers to learn 


\author{
International Journal of Economics, Business and Accounting Research (IJEBAR) \\ Peer Reviewed - International Journal \\ Vol-4, Issue-2, 2020 (IJEBAR) \\ E-ISSN: 2614-1280 P-ISSN 2622-4771 \\ https://jurnal.stie-aas.ac.id/index.php/IJEBAR
}

and then drawn conclusions,(Cristea, 2016) cited in (Setyaleksana, Suharyono, \& Yulianto, 2017), The population in this study is all respondents who filled out a questionnaire as many as 128 respondents. While the sample according to(Sumarni, 2019) cited in (Nelwan, Mandey, and Bhaskara, 2014)is part of the number and characteristics possessed by this population. The samples in this study were 86 respondents.

\title{
Operational Definition and Measurement of Variables
}

The operational definition is a definition given in a variable by giving meaning or specification of activities that will be used to measure these variables. Understanding these operations and then broken down into the indicators used in each variable.

\section{Service quality}

The quality of academic services are provided by the customer values the extent of academic services are provided in accordance with customer expectations(Sapri \& Finch, 2009), Customers in this case the student would say that academic service quality if it according to their specifications. The quality of academic services in this study is the value given on how good the academic services provided able to match the expectations of students.

\section{Education facilities}

The educational facilities at the college represents support for the implementation of the process of academic services. Amenities in education means everything physical and material, which can facilitate the implementation process of learning, such as the availability of a place of learning, classroom supplies, teaching aids learning, textbooks, library, pratikum equipment and laboratory fittings. Real form at the college facilities such as campus buildings, classrooms, laboratories, internet facilities, library, cafeteria, classroom equipment that can be used in the learning process. The dimensions of the college facilities include flexibility, structuring, good quality, feasibility of use, completeness, according to need, academic support, good design,(Azam, 2018)

\section{Student satisfaction}

According to(Chandra et al., 2018)satisfaction is the level of feeling where someone stated results of the comparison of the performance of products (services) received as expected. Satisfaction is the level of one's feelings after comparing the performance (results) are perceived with expectations(Kurbani, 2017), Departing from the basic concept of customer satisfaction, higher education is essentially a service industry that provides services or educational services which aim to provide satisfaction to its customers (students). Student satisfaction will be achieved when there is a match between the academic services provided to students with student expectations. academic student satisfaction for services received visits from the correspondence between expectations and performance of the services it receives(Saif, 2014),

\footnotetext{
Analysis method

Validity test

Validity indicates the degree to which an instrument able to measure what should be measured. Validity is the degree of accuracy of the data actually happened on the object of research with data that can be reported by researchers. Thus the valid data is data "tidk different" between the data reported by researchers with the word actually happened on the object of study(Octabriyantiningtyas, Syriac, and Jatmiko, 2019),
} 
International Journal of Economics, Business and Accounting Research (IJEBAR)

Peer Reviewed - International Journal

Vol-4, Issue-2, 2020 (IJEBAR)

E-ISSN: 2614-1280 P-ISSN 2622-4771

https://jurnal.stie-aas.ac.id/index.php/IJEBAR

\section{Test Reliability}

(Dirgantari, 2012) cited in (Fatona, 2010)Reliability is a tool to measure a questionnaire which is an indicator of a variable. Reliability with respect to the degree of consistency and stability of the data or findings. In view of positivistic (quantitative), the data is declared reliable if two or more researchers within the same object produces the same data, or the same researchers in different time generate the same data, or a bunch of data when broken down show different data.

\section{Research Result}

\section{Validity and Reliability Testing}

Validity and reliability of the respondents to see the validity and reliabelnya research instruments used. According Sugiyono (2009: 352) cited in(Kesuma, Hadiwidjojo, Wiagustini, \& Rohman, 2013) test performed after instrument / questionnaire is completed, the instrument then tested in a population from which the sample was taken.

\section{Validity test}

Table 4.1

\section{Correlations}

\begin{tabular}{|c|c|c|c|c|c|}
\hline & & X1.1 & $\mathrm{X} 1.2$ & $\mathrm{X} 1.3$ & $\begin{array}{l}\text { TOTAL } \\
\text { X1 }\end{array}$ \\
\hline X1.1 & $\begin{array}{l}\text { Pearson } \\
\text { Correlation } \\
\text { Sig. (2-tailed) } \\
\mathrm{N}\end{array}$ & 88 & $\begin{array}{l}, \quad 696 \\
* * \\
, 000 \\
88 \\
\end{array}$ & $\begin{array}{l}, \quad 470 \\
* * \\
, 000 \\
88 \\
\end{array}$ & $\begin{array}{l}, 873 * * \\
, 000 \\
88\end{array}$ \\
\hline $\mathrm{X} 1.2$ & $\begin{array}{l}\text { Pearson } \\
\text { Correlation } \\
\text { Sig. (2-tailed) } \\
\mathrm{N}\end{array}$ & $\begin{array}{l}, \quad 696 \\
* * \\
, 000 \\
88 \\
\end{array}$ & 88 & $\begin{array}{l}, \quad 438 \\
* * \\
, 000 \\
88 \\
\end{array}$ & $\begin{array}{l}, 878 * * \\
, 000 \\
88\end{array}$ \\
\hline $\mathrm{X} 1.3$ & $\begin{array}{l}\text { Pearson } \\
\text { Correlation } \\
\text { Sig. (2-tailed) } \\
\text { N }\end{array}$ & $\begin{array}{l}, \quad 470 \\
* * \\
, 000 \\
88\end{array}$ & $\begin{array}{l}, \quad 438 \\
* * \\
, 000 \\
88\end{array}$ & 88 & $\begin{array}{l}, 738 * * \\
, 000 \\
88\end{array}$ \\
\hline $\begin{array}{l}\text { TOTAL } \\
\_\mathrm{X} 1\end{array}$ & $\begin{array}{l}\text { Pearson } \\
\text { Correlation } \\
\text { Sig. (2-tailed) } \\
\text { N }\end{array}$ & $\begin{array}{l}, \quad 873 \\
* * \\
, 000 \\
88\end{array}$ & $\begin{array}{l}, \quad 878 \\
* * \\
, 000 \\
88\end{array}$ & $\begin{array}{l}, \quad 738 \\
* * \\
, 000 \\
88\end{array}$ & 88 \\
\hline
\end{tabular}

**. Correlation is significant at the 0:01 level (2-tailed). 
International Journal of Economics, Business and Accounting Research (IJEBAR)

Peer Reviewed - International Journal

Vol-4, Issue-2, 2020 (IJEBAR)

E-ISSN: 2614-1280 P-ISSN 2622-4771

https://jurnal.stie-aas.ac.id/index.php/IJEBAR

Table 4.2

\begin{tabular}{|c|c|c|c|c|c|c|}
\hline & & $\mathrm{X} 2.1$ & $\mathrm{X} 2.2$ & $\mathrm{X} 2.3$ & $\mathrm{X} 2.4$ & $\begin{array}{l}\text { TOTAL } \\
\quad \mathrm{X} 2 \\
\end{array}$ \\
\hline $\mathrm{X} 2.1$ & $\begin{array}{l}\text { Pearson } \\
\text { Correlation } \\
\text { Sig. (2-tailed) } \\
\mathrm{N}\end{array}$ & $\begin{array}{l}1 \\
88 \\
\end{array}$ & $\begin{array}{l}, \quad 610 \\
* * \\
000 \\
88 \\
\end{array}$ & $\begin{array}{l}, \quad 329 \\
* * \\
.002 \\
88 \\
\end{array}$ & $\begin{array}{l}, \quad 365 \\
* * \\
000 \\
88 \\
\end{array}$ & $\begin{array}{l}, 757 * * \\
, 000 \\
88\end{array}$ \\
\hline $\mathrm{X} 2.2$ & $\begin{array}{l}\text { Pearson } \\
\text { Correlation } \\
\text { Sig. (2-tailed) } \\
\mathrm{N}\end{array}$ & $\begin{array}{l}, \quad 610 \\
* * \\
000 \\
88\end{array}$ & 88 & $\begin{array}{l}, \quad 522 \\
* * \\
, 000 \\
88 \\
\end{array}$ & $\begin{array}{l}, \quad 425 \\
* * \\
, 000 \\
88\end{array}$ & $\begin{array}{l}, 849 * * \\
, 000 \\
88\end{array}$ \\
\hline $\mathrm{X} 2.3$ & $\begin{array}{l}\text { Pearson } \\
\text { Correlation } \\
\text { Sig. (2-tailed) } \\
\mathrm{N}\end{array}$ & $\begin{array}{l}, \quad 329 \\
* * \\
.002 \\
88\end{array}$ & $\begin{array}{l}, \quad 522 \\
* * \\
, 000 \\
88\end{array}$ & 88 & $\begin{array}{l}270 * \\
.011 \\
88 \\
\end{array}$ & $\begin{array}{l}, 676 * * \\
, 000 \\
88\end{array}$ \\
\hline $\mathrm{X} 2.4$ & $\begin{array}{l}\text { Pearson } \\
\text { Correlation } \\
\text { Sig. (2-tailed) } \\
\mathrm{N}\end{array}$ & $\begin{array}{l}, \quad 365 \\
* * \\
, 000 \\
88\end{array}$ & $\begin{array}{l}, \quad 425 \\
* * \\
, 000 \\
88 \\
\end{array}$ & $\begin{array}{l}270 * \\
.011 \\
88 \\
\end{array}$ & 88 & $\begin{array}{l}, 719 * * \\
, 000 \\
88\end{array}$ \\
\hline $\begin{array}{l}\text { TOTAL } \\
\text {-X2 }\end{array}$ & $\begin{array}{l}\text { Pearson } \\
\text { Correlation } \\
\text { Sig. (2-tailed) } \\
\text { N }\end{array}$ & $\begin{array}{l}, \quad 757 \\
* * \\
000 \\
88\end{array}$ & $\begin{array}{l}{ }_{* *} 849 \\
, 000 \\
88\end{array}$ & $\begin{array}{l}, \quad 676 \\
* * \\
, 000 \\
88\end{array}$ & $\begin{array}{l}, \quad 719 \\
* * \\
, 000 \\
88\end{array}$ & 88 \\
\hline
\end{tabular}

**. Correlation is significant at the 0:01 level (2-tailed).

*. Correlation is significant at the 0:05 level (2-tailed).

Table 4.3 
International Journal of Economics, Business and Accounting Research (IJEBAR)

Peer Reviewed - International Journal

Vol-4, Issue-2, 2020 (IJEBAR)

E-ISSN: 2614-1280 P-ISSN 2622-4771

https://jurnal.stie-aas.ac.id/index.php/IJEBAR

\begin{tabular}{|c|c|c|c|c|c|}
\hline Y.2 & $\begin{array}{l}\text { Pearson } \\
\text { Correlation } \\
\text { Sig. (2-tailed) } \\
\mathrm{N}\end{array}$ & $\begin{array}{l}, 257 * \\
.015 \\
88 \\
\end{array}$ & 88 & $\begin{array}{l}, \quad 646 \\
* * \\
, 000 \\
88 \\
\end{array}$ & $\begin{array}{l}, \quad 824 \\
* * \\
, 000 \\
88 \\
\end{array}$ \\
\hline Y.3 & $\begin{array}{l}\text { Pearson } \\
\text { Correlation } \\
\text { Sig. (2-tailed) } \\
\mathrm{N}\end{array}$ & $\begin{array}{l}, 219 * \\
, 040 \\
88\end{array}$ & $\begin{array}{l}, \quad 646 \\
* * \\
, 000 \\
88 \\
\end{array}$ & 88 & $\begin{array}{l}{ }^{2} \quad 732 \\
* * \\
, 000 \\
88\end{array}$ \\
\hline $\begin{array}{l}\text { TOTA } \\
\text { L_Y }\end{array}$ & $\begin{array}{l}\text { Pearson } \\
\text { Correlation } \\
\text { Sig. (2-tailed) } \\
\text { N }\end{array}$ & $\begin{array}{l}, \quad 714 \\
* * \\
000 \\
88\end{array}$ & $\begin{array}{l}, \quad 824 \\
* * \\
, 000 \\
88\end{array}$ & $\begin{array}{l}, \quad 732 \\
* * \\
, 000 \\
88\end{array}$ & 88 \\
\hline
\end{tabular}

*. Correlation is significant at the 0:05 level (2-tailed).

**. Correlation is significant at the 0:01 level (2-tailed).

Table 4.1, Table 4.2 and Table 4.3 shows the overall item to the variable is a valid question because it is above the critical value rtabel $=0.2096$ (from the table Spearman Rho, $\mathrm{df}=(\mathrm{N}-2)$ so that the grains of the instrument can be used to measure the research variables.

\section{Test Reliability}

Table 4.4 X1

Reliability Statistics

\begin{tabular}{|l|l|}
\hline $\begin{array}{l}\text { Cronbach's } \\
\text { Alpha }\end{array}$ & $\begin{array}{l}\mathrm{N} \text { of } \\
\text { Items }\end{array}$ \\
\hline, 776 & 3 \\
\hline
\end{tabular}

Table 4.5 X2

Reliability Statistics

\begin{tabular}{|l|l|}
\hline $\begin{array}{l}\text { Cronbach's } \\
\text { Alpha }\end{array}$ & $\begin{array}{l}\mathrm{N} \text { of } \\
\text { Items }\end{array}$ \\
\hline, 739 & 4 \\
\hline
\end{tabular}


International Journal of Economics, Business and Accounting Research (IJEBAR)

Peer Reviewed - International Journal

Vol-4, Issue-2, 2020 (IJEBAR)

E-ISSN: 2614-1280 P-ISSN 2622-4771

https://jurnal.stie-aas.ac.id/index.php/IJEBAR

Table 4.6 Y

Reliability Statistics

\begin{tabular}{|l|l|}
\hline $\begin{array}{l}\text { Cronbach's } \\
\text { Alpha }\end{array}$ & $\begin{array}{l}\mathrm{N} \text { of } \\
\text { Items }\end{array}$ \\
\hline, 688 & 3 \\
\hline
\end{tabular}

Based on the results of the reliability test are shown in the tables above, then all variables in this study expressed a reliable instrument. This is in accordance with predetermined criteria wherein the resulting Cronbach alpha values of each variable is above the critical value suggested. Suliyanto (2005: 51) cited in(Yulianti, Sjahruddin, and Tahir, 2015)states the instrument can be said reliably (reliable) if it has a reliability coefficient of reliability> alpha value or when the value of alpha> of table Spearman Rho, $\mathrm{df}=(\alpha, \mathrm{n}-2)$ means that the variable is declared unreliable. Reliability of research instrument reliability coefficient of $0.776 ; 0.739 ; 0.688$ (instrument reliability value> 0.6 ), meaning that the variable $\mathrm{X} 1, \mathrm{X} 2$, and $\mathrm{Y}$ otherwise reliable. So that data analysis can be continued to predict the relationship between variables in accordance with the hypothesis.

\section{Hypothesis test}

Testing Hypotheses $\mathrm{H} 1$ and $\mathrm{H} 2$ with $\mathrm{T}$ test

Coefficientsa

\begin{tabular}{|c|c|c|c|c|c|c|}
\hline \multirow[b]{2}{*}{ Mode } & & \multicolumn{2}{|c|}{ Coefficients unstandardized } & \multirow{2}{*}{$\begin{array}{l}\text { standardized } \\
\text { Coefficients } \\
\text { Beta }\end{array}$} & \multirow[b]{2}{*}{$\mathrm{t}$} & \multirow[b]{2}{*}{ Sig. } \\
\hline & & B & Std. Error & & & \\
\hline & $\begin{array}{l}\text { Quality of Academic } \\
\text { Services (X1) }\end{array}$ &, 147 &, 101 &, 134 & 1.452 &, 150 \\
\hline & Education Facilities (X2) &, 363 &, 054 &, 622 & 6.762 &, 000 \\
\hline
\end{tabular}

a. Dependent Variable: Student Satisfaction (Y)

First Hypothesis Testing (H1)

Sig value is known to influence the Academic Quality of Service (X1) to the Student Satisfaction (Y) is equal to $0.150>0.05$ and $1.452 \mathrm{t}$ count $<\mathrm{t}$ table1,992, so it can be concluded that $\mathrm{H} 1$ is rejected, which means there is no influence Quality of Academic Services(X1) to Student satisfaction $(\mathrm{Y})$.

\section{Testing the second hypothesis $(\mathrm{H} 2)$}

It is known to influence the value of Sig Educational Facilities (X2) on the Student Satisfaction (Y) of $0.000<0.05$ and $6.762 \mathrm{t}$ count $>\mathrm{t}$ table 1,992 , so it can be concluded that the $\mathrm{H} 2$ received, which means there is influence of Educational Facilities (X2) to the Student Satisfaction (Y). 
International Journal of Economics, Business and Accounting Research (IJEBAR)

Peer Reviewed - International Journal

Vol-4, Issue-2, 2020 (IJEBAR)

E-ISSN: 2614-1280 P-ISSN 2622-4771

https://jurnal.stie-aas.ac.id/index.php/IJEBAR

\section{H3 Hypothesis Testing with Test F}

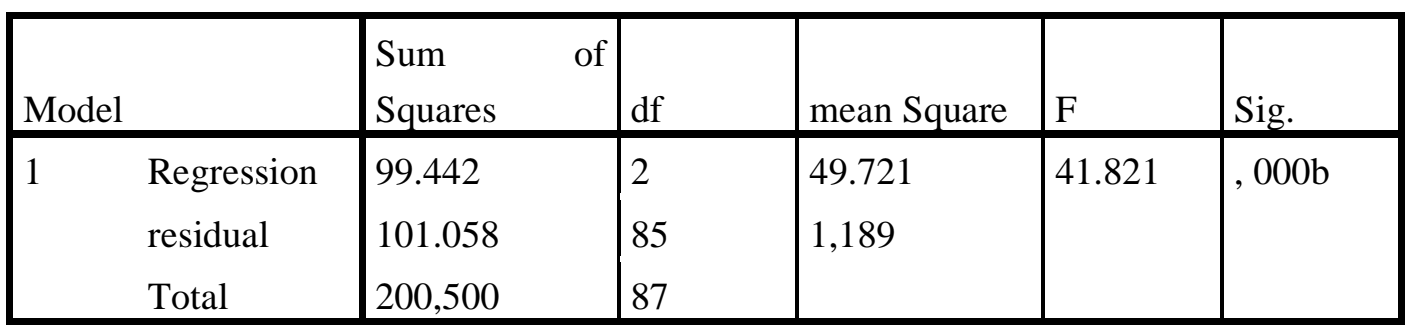

a. Dependent Variable: Student Satisfaction (Y)

b. Predictors: (Constant), Educational Facilities (X2), Quality of Academic Services (X1)

Based on the above output is known to influence the value of Sig Academic Quality of Service (X1) and Education Facilities (X2) simultaneously on Student Satisfaction (Y) of $0.000<0.05$ and F count 41.821> F table 3.10, so it can be concluded that $\mathrm{H} 3$ received, which means there is influence of Quality of Academic Services (X1) and Education facilities (X2) simultaneously on Student Satisfaction (Y).

\section{Conclusions and recommendations}

\section{Conclusions}

a. Taken together there is the influence of academic services and facilities quality education to the student satisfaction

b. Partially no effect on the quality of academic services of student satisfaction

c. Partially there are significant educational facilities to the students satisfaction

\section{Suggestions}

From the results of research on the quality of academic services and education to the student satisfaction fasisilitas some recommendations that could be suggested are:

a. For the quality of academic services,

b. which should be a priority to be improved is the personnel that directly confront the students need to be equipped with special skills of students while serving as one of the stakeholders.

a. Improvements to facilities

c. education should refer to the real needs of students. Facilities that need priority to be remedied or improved quality is refresentatif lecture room, whiteboard facilities, fan, LCD, and wifi / internet access as supporting the lecture.

a. Identify the need for more

d. depth needs to be done to enable the compatibility between

e. the needs of students as one of the stakeholders with the procurement of facilities and the establishment of programs to improve the quality of service quality.

\section{References}

Azam, A. (2018). Service Quality Dimensions and Students' Satisfaction: A study of the Saudi Arabian Private Higher Education Institutions. European Online Journal of Natural and Social Sciences 
International Journal of Economics, Business and Accounting Research (IJEBAR)

Peer Reviewed - International Journal

Vol-4, Issue-2, 2020 (IJEBAR)

E-ISSN: 2614-1280 P-ISSN 2622-4771

https://jurnal.stie-aas.ac.id/index.php/IJEBAR

2018, 7 (2), 275-284.

Chandra, T. Ng, M. Chandra, S., \& Priyono. (2018). The effect of service quality on student satisfaction and student loyalty: An empirical study. Journal of Social Studies Education Research, 9 (3), 109131. https://doi.org/10.17499/jsser.12590

Cristea, A. (2016). No.主観的健康感を中心とした在宅高齢者における健康関連指標 に関 する 共 分散 構造 分析Title. Revista Brasileira de Ergonomia, 9 (2), 10. https://doi.org/10.5151/cidi2017-060

Dirgantari, PD (2012). Effect of Quality of Services Education Student Satisfaction and Improving Image Impact on Universities Towards a World Class University (Study on Foreign Students at ITB, UNPAD, and UPI). Journal of Management Science and Business, 3 (2). https://doi.org/10.17509/jimb.v3i2.1039

Dora, YM (2017). Effect Analysis of Service Quality, Educational Facilities, and Method of Learning, Student Satisfaction and Loyalty to Students - Studies in the University of Widyatama Bandung. European Journal of Social Sciences of Education and Research, 10 (1), 16. https://doi.org/10.26417/ejser.v10i1.p16-27

Fatona, S. (2010). Affecting Service Quality Satisfaction Loyalty And Its Relevance. Journal of Management Dynamics, 1 (1), 41-46. https://doi.org/10.15294/jdm.v1i1.2448

Kesuma, I., Hadiwidjojo, D., Wiagustini, N., \& Rohman, F. (2013). Service Quality Influence on Patient Loyalty: Customer Relationship Management as Mediation Variable (Study on Private Hospital Industry in Denpasar). International Journal of Business and Commerce, 2 (12), 1-14.

Kurbani, A. (2017). Effect of Quality of Academic Services and Education Facilities Student Satisfaction Study at the University of PGRI Palembang. Wahana Media Journal of Economics, 13 (4), 23.

Marthalina. (2018). Analysis of the quality of academic services and student satisfaction in IPDN campus jakarta. HRM Journal, 5 (1), 1-18.

Mestrovic, D. (2018). The Impact of Service Quality on Students' Satisfaction and the Word-of-Mouth: The Case of the University of Rijeka Departments. SSRN Electronic Journal, (October). https://doi.org/10.2139/ssrn.3282466

Napitupulu, D., Rahim, R., Abdullah, D., Setiawan, MI, Abdillah, LA, Ahmar, US, ... Pranolo, A. (2018). Analysis of Student Satisfaction Toward Quality of Service Facility. Journal of Physics: Conference Series, 954 (1). https://doi.org/10.1088/1742-6596/954/1/012019

Nelwan, O., Mandey, S., \& Bhaskara, S. (2014). Customer Relationship Management (Crm) and Personal Selling Influence on Consumer Satisfaction In Virgo Pt Express Tours \& Travel Manado. Journal of Economic Research, Management, Business and Accounting, 2 (1), 99-110.

Nugroho, NE, Cahyono, KE, \& Suryawirawan, OA (2018). Pengaruhkualitas Academic Services Student Satisfaction School of Economics Indonesia (STESIA) Surabaya. 978-979.

Octabriyantiningtyas, D., Suryani, E., \& Jatmiko, AR (2019). Modeling customer satisfaction with the service quality of e-money in increasing profit of Pt. Telekomunikasi Indonesia. Procedia Computer Science, 161, 943-950. https://doi.org/10.1016/j.procs.2019.11.203

Personal, M., \& Archive, R. (2017). Munich Personal RePEc Archive The impact of academic service quality on student satisfaction. (80 878).

Prof. Dr. I Made Yudana, M., \& Prof. Dr. I Nyoman Natajaya, M. (2013). Academic Services Quality Impact Satisfaction And Loyalty Tourism College Students In Nusa Dua Bali. Journal of Educational Administration, 4 (1). https://doi.org/10.23887/japi.v4i1.916

Saif, NI (2014). The Effect of Service Quality on Student Satisfaction: A Field Study for Health Services Administration Students. International Journal of Humanities and Social Science, 4 (8), 172-181. Retrieved from http://www.ijhssnet.com/journals/Vol_4_No_8_June_2014/18.pdf

Sapri, M., \& Finch, E. (2009). Factors That Influence Student's Level of Satisfaction With Regards To Higher Educational Facilities Services. Malaysian Journal of Real Estate, 4 (1), 34-51.

International Journal of Economics, Business and Accounting Research (IJEBAR)

Page 149 
International Journal of Economics, Business and Accounting Research (IJEBAR)

Peer Reviewed - International Journal

Vol-4, Issue-2, 2020 (IJEBAR)

E-ISSN: 2614-1280 P-ISSN 2622-4771

https://jurnal.stie-aas.ac.id/index.php/IJEBAR

Setyaleksana, BY, Suharyono, S., \& Yulianto, E. (2017). INFLUENCE OF CUSTOMER RELATIONSHIP MANAGEMENT (CRM) CUSTOMER SATISFACTION AND LOYALTY (Survey on Customer GraPARI Telkomsel in Malang). S1 Business Administration Journal of UB, $46(1), 45-51$.

Shaylide, IS (2014). Effect of Academic Service Quality And Cost Of Education Student Satisfaction. UPI Journal of Educational Administration, 21 (2), 1-11.

Sumarni, Y. (2019). Influence of Service Quality of Academic Administration and Student Satisfaction Student Faculty of Economics and Business Islam Iain Bengkulu. AL-Ilmi BAABU Journal: Economics and Islamic Banking, 3 (1), 71-91. https://doi.org/10.29300/ba.v3i1.1474

Usman, A. (2010). The Impact of Service Quality on Students' Satisfaction in Higher Education Institutes of Punjab. Journal of Management Research, 2 (2). https://doi.org/10.5296/jmr.v2i2.418

Yulianti, L., Sjahruddin, H., \& Tahir, B. (2015). Implementation of Customer Relationship Management (CRM) Satisfaction and Customer Loyalty Brand Samsung Android Smartphone Users. JOURNAL OF ORGANIZATION and management of, 3 (3), 1-15. 